\title{
OS INTÉRPRETES DO BRASIL: PENSAMENTO SOCIOPOLÍTICO LASTREADO NO FLUXO DE IDEIAS, NARRATIVAS E REALIDADES NA BUSCA DE UMA IDENTIDADE NACIONAL BRASILEIRA
}

José Ricardo Martins ${ }^{1}$

\begin{abstract}
RESUMO: Este artigo procura compreender o Brasil a partir do fluxo histórico de pensamento de seus intérpretes e investiga se há uma questão central que permeia as diversas narrativas, sejam elas de cunho político, sociológico ou outros. Apuramos que a busca por uma identidade brasileira e a vontade de nos entendermos como povo está presente na escrita dos diversos "intérpretes do Brasil" aqui examinados, como Sérgio Buarque de Holanda, Victor Nunes Leal, Raymundo Faoro, Florestan Fernandes, Jessé Souza, entre outros. Da mesma forma, verificou-se que a constituição da identidade brasileira incorpora conceitos como a subalternidade, a subcidadania, o mando e a submissão, relações de dependência, desigualdade, passividade, fatalismo, familismo, cordialidade, entre outras qualificações que foram forjadas por meio da colonialidade, do patrimonialismo, da dominação estamental, coronelismo, autoritarismo e autocracia, democracia restrita, capitalismo dependente, violência física e simbólica, exclusão, relações servis e de privilégios, tão presentes na realidade brasileira.
\end{abstract}

PALAVRAS-CHAVE: Brasil; intérpretes do Brasil; pensamento sócio-político brasileiro; identidade brasileira; colonialidade; subcidadania.

\section{THE INTERPRETERS OF BRAZIL: SOCIOPOLITICAL THOUGHT BASED ON IDEAS FLOW, NARRATIVE AND REALITIES IN SEARCH OF A BRAZILIAN NATIONAL IDENTITY}

\begin{abstract}
This article aims understand Brazil from the historical flow of thought from their interpreters and investigates whether there is a central issue that permeates the various narratives, whether of a political, sociological or other. Found that the search for a Brazilian identity and the will to understand us as a people is present in the writing of several "Brazil interpreters" examined here, as Sérgio Buarque de Holanda, Victor Nunes Leal, Raymundo Faoro, Florestan Fernandes, Jessé Souza, among others. Similarly, it was found that the constitution of the Brazilian identity encompasses concepts such as subordination, the undercitizenship, submission, dependency relationships, inequality, passivity, fatalism, familism, cordiality, among other qualifications that were forged through coloniality, patrimonialism, the estamental domination, "colonelism", authoritarianism and autocracy, restricted democracy, dependent capitalism, physical and symbolic violence, exclusion, servile relations and privileges, so well present in the Brazilian life.
\end{abstract}

Keywords: Brazil; Brazil interpreters; Brazilian socio-political thought; Brazilian identity; coloniality; undercitizenship.

- Enviado em 13/05/2017

- Aprovado em 28/06/2017

\footnotetext{
${ }^{1}$ Doutor em Sociologia pela Universidade Federal do Paraná (UFPR), sob a orientação dos professores doutores Ricardo Costa de Oliveira (PPG em Sociologia, UFPR) e Mario Procopiuck (PPG em Gestão Urbana, PUC-PR); bolsista Capes. Meus agradecimentos ao Prof. Mario Procopiuck pelas sugestões e direcionamentos. E-mail: ricardo@brazilone.net
} 


\section{INTRODUÇÃO}

Muitos são os empreendimentos narrativos e analíticos que foram realizados na tentativa de compreender e explicar o Brasil a partir das diferentes áreas do conhecimento. Alguns foram historiadores, literatos e geógrafos, outros economistas e juristas, mas muitos ainda foram sociólogos, cientistas políticos, antropólogos e filósofos. Com o acúmulo de conhecimento desses diversos estudos em seus distintos formatos, uns falam em linhagens do pensamento político e social brasileiro, como Gildo Marçal Brandão, já outros fazem uma genealogia ou ainda "lições" sobre o Brasil, como Bernardo Ricupero.

A riqueza dos diferentes intentos de explicar ou interpretar o Brasil, a partir da organização social e política, ou seja, a partir de suas organizações, seus atores e a distribuição do poder, está no fato de que estes são pensados a partir de diferentes ângulos do escopo ideológico. Uns são a partir de um ideário conservador, outros liberais e muitos deles a partir de uma visão marxista.

A temática das narrativas e do conteúdo dos ensaios ganha diversidade ao passar dos anos - certamente pelo fato de serem pensadas a partir de diferentes áreas do conhecimento e da própria complexidade da realidade brasileira, atual e pretérita. Em meio a essa diversidade, há uma questão central que permeia e une as diversas narrativas? Certamente sim, e, a nosso ver, é a busca pela identidade brasileira. Esta questão está bem presente nos estudos da primeira metade do século XX, mas não é exclusiva destes. Esses autores, ao analisar a formação da nação, por meio de sua historiografia, economia, política e a da própria sociedade, colocam-se e se dispõem a responder questões como: quem somos? como nos identificamos? o que nos congrega? o que nos diferencia dos outros? porque somos o que somos? como nos constituímos desse modo? como chegamos ao que somos?

Adotando um escopo epistemológico mais amplo, chamamos esses autores de "intérpretes do Brasil". Trata-se de interpretações gerais clássicas da formação da sociedade brasileira formuladas entre 1914 e 1975. Esses autores indagam sobre a própria "natureza" da sociedade que se veio formando no Brasil desde a Colônia.

A justificativa da escolha dos autores é pautada no fluxo histórico de ideias. Dentre estes, consideramos como "ícones" intérpretes do Brasil (e suas obras seminais) os que estão marcados com seta em preta na cronologia em formato de fluxograma que consta na figura 1 . Contudo, a 
riqueza e a acuidade das análises de outros autores, com apreciações de questões mais pontuais que muito auxiliam na compreensão do Brasil e de sua identidade, foram de tal monta que quisemos abrir o leque e trazer para esta pesquisa a contribuição destes autores, que chamamos de "complementares". Estes estão assinalados com a seta preta e vazadas no fluxograma abaixo.

A lista dos "tradicionais" intérpretes do Brasil foi expandida - ainda que incompleta -, pois a riqueza de ideias e a contribuição desses autores são valorosas e pertinentes para compreender e explicar o Brasil. Expandimos o rol de autores, numa escolha de identificação acadêmica, dando ênfase aos autores da política, elegendo os que consideramos mais representativos para atingir o objetivo proposto neste trabalho. De qualquer forma, procuramos apresentar marcos importante da historiografia da sociedade brasileira.

Ademais, não é aprofundada ou esgotada toda a extensão e complexidade do pensamento e das obras dos autores aqui apresentados. Por questões de espaço, expomos uma ou duas ideias centrais desses autores nas quais podem-se observar os traços da identidade brasileira e da nação sendo forjados.

Por outro lado, apenas a título de referencial, se almejarmos fornecer um guia de autores que produziram importantes estudos sobre o Brasil, incluindo áreas como a Economia, Geografia, Política, Sociologia, Antropologia, Literatura e a História, outros autores e suas respectivas obras seminais, ainda podem, com justeza, completar nossa lista de "intérpretes do Brasil". Estes estão assinalados no nosso fluxograma com seta branca. Contudo, por questões de espaço, a obra e as contribuições desses autores não são tratadas aqui. 
Figura 1 - Fluxograma cronológico dos intérpretes do Brasil e suas obras seminais

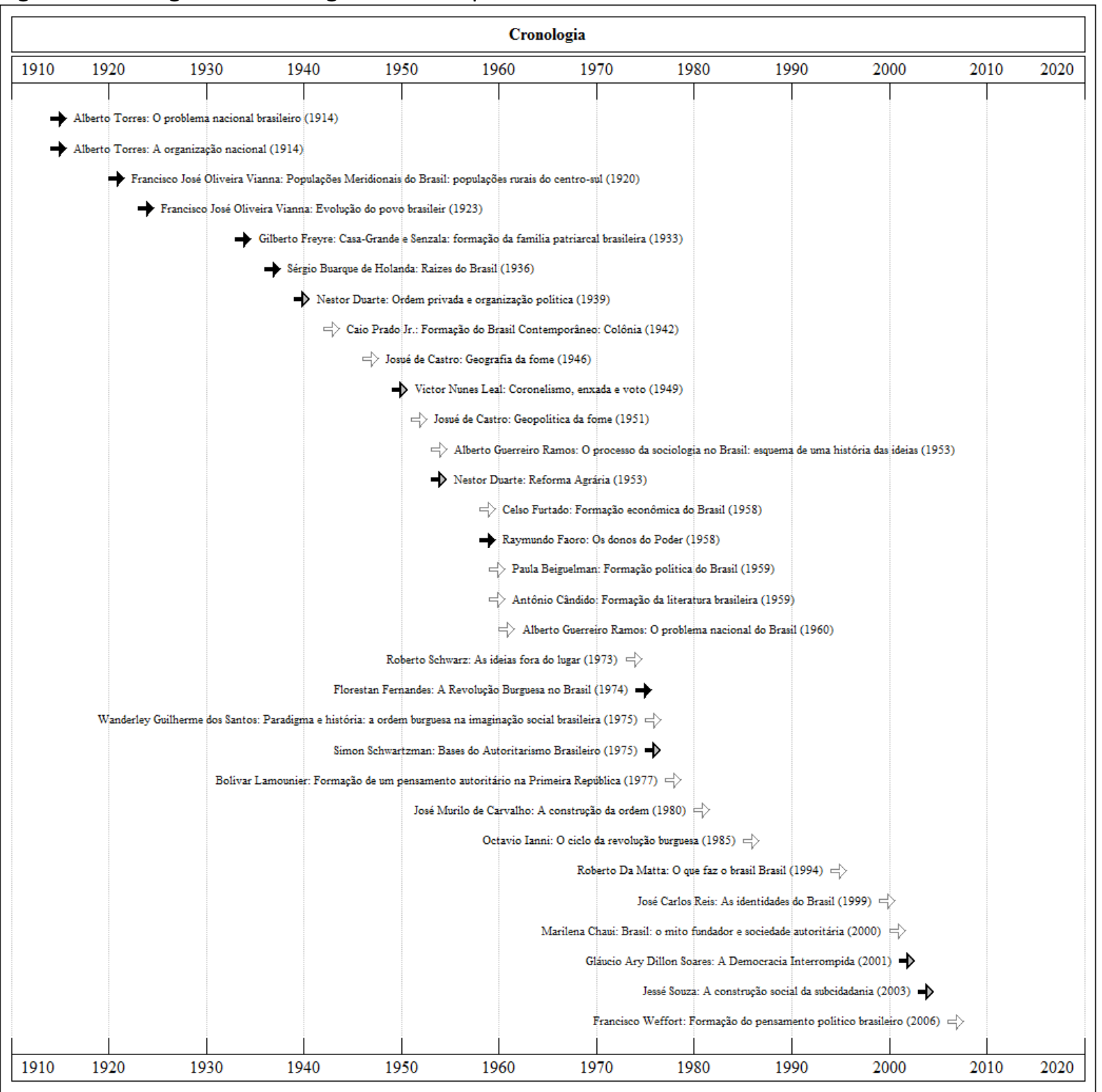

Fonte: o autor e Mario Procopiuck (2016)

Observa-se que na cronologia acima há uma densidade e uma amplitude maior na interpretação do Brasil no início do fluxo e menor ao final, o que é natural em decorrência do próprio processo histórico, migração e sedimentação de ideias. Ou seja, as interpretações mais recentes não têm a pretensão de explicar o Brasil como um todo, mas explicam fenômenos específicos (como o coronelismo, autoritarismo, democracia, burguesia, subcidadania, entre outros) ou fenômenos em períodos específicos da história do país. 
Portanto, este trabalho tem o objetivo de apresentar, numa perspectiva histórica, a principal ou as ideias basilares de alguns desses intérpretes do Brasil - sem esgotar seu pensamento - e verificar se há um fio condutor na narrativa da formação da sociedade brasileira e que responde à pergunta que constitui nosso problema de pesquisa: há uma identidade brasileira que subjaz nas narrativas dos intérpretes do Brasil? Tal empreitada se justifica pelo fato de que conhecer a formação sociopolítica de seu país é tarefa primeira de todo cidadão, sobretudo de um cientista social. Nossa hipótese de trabalho assenta na identidade como questão central dos intérpretes do Brasil.

Além desta introdução, o trabalho é composto por outras quatro secções: a primeira trata do debate da questão inicial que é a identidade e a necessidade de uma identidade na formação de uma nação; a segunda aborda os representantes do pensamento autoritário brasileiro; a terceira trata dos intérpretes (clássicos) do Brasil; e a última apresenta os demais pensadores que foram incorporados ao rol dos intérpretes do Brasil e suas principais contribuições. Por fim, tecemos os comentários finais, fazendo nossa síntese apreciativa do périplo aqui realizado, a título de conclusão.

\section{IDENTIDADE: A QUESTÃO DOS INTÉRPRETES DO BRASIL}

A questão da identidade é a primeira e a mais elementar das grandes questões que o ser humano se coloca. A Filosofia, a Psicologia e a Religião a colocam no nível pessoal, do indivíduo que busca se compreender e explicar a si mesmo, a sua relação com os outros e como ele é parte do cosmos. A Ciência Política trabalha a identidade no nível de pertencimento de uma nação, povo ou grupo político. Desse viés derivam os nacionalismos, uma força motriz capaz de unir povos e os fazerem dar suas vidas pela pátria.

\section{A necessária busca de uma identidade nacional}

Toda identidade nacional é uma narrativa (HALL, 2006). E as narrativas organizadas são um discurso e este, muitas vezes, baseia-se num interesse determinado e, sobretudo, no poder. Assim, a identidade fundamenta-se na continuidade do poder. Inventa-se tradições do passado 
para criar cultura e identidade nacional; cria-se o mito fundacional, que são mitos de origem, da instituição da nação, como o do Rei Arthur na Inglaterra, Pedro Álvares Cabral no Brasil, além de Tiradentes ser alçado ao título de mártir da independência ou ainda Simón Bolívar, o libertador para vários países sul-americanos.

A narrativa da nação é produzida por escritores e intelectuais. Cada nação constrói suas narrativas com seus heróis. Quem imagina, pensa ou representa, tem interesse. Segundo Foucault (1996), estes são discursos como enunciados estruturantes da nação.

Cada paradigma teórico organiza uma narrativa. Caio Prado Júnior, por exemplo, tece sua narrativa marxista, a parir das lutas de classes. Já Sérgio Buarque de Holanda, a partir de uma narrativa liberal weberiana.

No Brasil, o primeiro momento de que se tem registro da nossa identidade foi durante a guerra de expulsão dos holandeses do nordeste do Brasil colônia em 1625 de Salvador e em 1654 de Recife. Estas guerras constituem um ponto forte da gênese identitária brasileira. Usualmente a guerra une um povo e fortalece o nacionalismo que se gera numa relação dialética, neste caso, contra o inimigo externo, os holandeses. Naquela ocasião, o termo "brasileiro" fora usado pela primeira vez para designar os que eram nascidos em solo colonial brasileiro. Para expulsar os holandeses, formou-se uma união de portugueses, colonos, escravos e índios que nunca acontecera antes. Aqui inventa-se a nação pela inclusão de suas várias etnias: índios, negros e europeus. Tal noção da miscigenação das raças na constituição da nação será retomada por Gilberto Freyre e constitui-se no argumento central de sua obra.

As grandes questões que os autores chamados de intérpretes do Brasil se puseram foram:

O que nos une? O que cria em nós um sentimento de pertencimento? O que nos faz brasileiros? Por que e para que fazer parte de uma nação? O que nos leva a matar ou morrer por nossa pátria? Essas são indagações que vários autores que se propuseram a estudar a identidade nacional se deparam e discutem até hoje. (ANDRADE, 2010)

Todas as ciências humanas e a Filosofia continuamente lançam novas luzes na compreensão do conceito de identidade. Kobena Mercer, crítico cultural, afirma que "a identidade somente se torna questão quando está em crise, quando algo que se supõe como fixo, coerente e estável é deslocado pela experiência da dúvida e da incerteza." (MERCER, 1990, in HALL, 2006, p. 9). Tal era a situação quando os primeiros intérpretes formularam suas narrativas: decretava-se o fim do Império, tendo uma organização política centralizada e passava-se à República 
descentralizada. Foi o ponto de inflexão que serviu de contexto para Alberto Torres e Oliveira Viana e, mesmo, as subsequentes narrativas de Gilberto Freyre e Sérgio Buarque de Holanda.

Benedict Anderson (1983) nos acautela que as identidades nacionais são, na maior parte das vezes, constructos elaborados e, muitas vezes, imaginados que estão, amiúde, a serviço de um grupo ou da nação inteira. A identidade nacional conduz ao nacionalismo e este pode formar uma força tão intensa que é capaz de destruir ou construir uma nação. Este fenômeno é percebido em diversos momentos na história do Brasil, desde o momento da Guerra dos Guararapes, tendo em vista a expulsão dos holandeses e a retomada do território colonial brasileiro, e mesmo as diversas negociações de fronteiras, como o Tratado de Madri, em 1750, conduzida por Alexandre de Gusmão, hoje patrono da diplomacia brasileira, ou ainda as negociações da formação final do "corpo da pátria" no início do século XX, realizadas pelo Barão do Rio Branco, dentre as quais destacamos a anexação do Acre, parte da Bolívia, concretizada pelo Tratado de Petrópolis em 1903.

Quando se perscruta por nossa identidade nacional, o questionamento fundamental a fazer é: o que atribui brasilidade ao brasileiro ou a um sujeito cultural brasileiro, como o carnaval? Ao replicar, chega-se ao âmago do que é ser brasileiro ou ao núcleo da identidade que resiste à equalização e distingue-se dela, como posto por Ruth Cardoso: “é o núcleo resistente à homogeneização e que pode ser semente de mudanças socioculturais" (CARDOSO, apud CASTELLS, 2000, p.ii).

\section{Identidade nacional e a "comunidade imaginada" brasileira}

Uma das formas mais comuns de identidade cultural é a identidade nacional. Aliás, esta é uma forma particular da identidade cultural. E como a identidade nacional está intrinsecamente implicada ao processo civilizador de uma nação, faremos uma breve abordagem deste tema.

Os principais elementos formadores da identidade de uma nação são: uma língua comum, heróis nacionais, festejos tradicionais e populares, gastronomia típica, valores comuns e sentimento de pertencimento, ou seja, a cultura nacional.

Conforme observou Stuart Hall (2006), a identidade nacional não está impressa nos genes de seus cidadãos, mas é o sentimento de pertencimento e de identificação que os faz parte de tal identidade. O filósofo Roger Scruton observou que 
A condição de homem exige que o indivíduo, embora exista e aja como ser autônomo, faça isso somente porque ele pode primeiramente identificar a si mesmo como algo mais amplo - como um membro de uma sociedade, grupo, classe, estado ou nação, de algum arranjo, ao qual ele pode até não dar um nome, mas que ele reconhece instintivamente como seu lar. (1986, p. 156).

$\mathrm{O}$ ato de pertencimento a uma nação nem sempre foi tal como hoje, "um atributo inerente da humanidade". (GELLNER, 1983, p. 6). Em tempos pré-modernos, o ato de pertencimento, a lealdade e a identificação eram dados às tribos, à religião, à região ou ainda, acrescentaria, ao soberano. Esses sentimentos

foram transferidos, gradualmente, nas sociedades ocidentais, à cultura nacional. As diferenças regionais e étnicas foram gradualmente sendo colocadas, de forma subordinada, sob aquilo que Gellner chama de 'teto político' do estado-nação. (HALL, 2006, p. 49).

Dessa forma, vê-se gradativamente surgir e consolidar as culturas e, por conseguinte, as identidades nacionais. É desnecessário observar que esses sentimentos de nacionalismo foram brotando à medida que os estados modernos foram surgindo. No caso do Brasil, vê-se, em nossa história colonial, bem antes do surgimento do estado independente brasileiro, os primeiros sinais de nacionalismo. Foi na Guerra de Guararapes, como já mencionado, na qual portugueses, colonos brasileiros, escravos negros e índios se uniram, formaram um exército e derrotaram o exército de mercenários dos invasores holandeses em Pernambuco. Nessa ocasião fora encontrada, pela primeira vez, a palavra "nação" referindo ao Brasil, mesmo sendo ainda uma colônia de Portugal.

A partir da epopeia de Guararapes, criaram-se muitos mitos, sendo um deles o da gentil integração multirracial brasileira ${ }^{2}$, na qual índios, negros e brancos lutam lado-a-lado para expulsar o inimigo invasor. Os chefes guerreiros de cada uma das raças são transformados em heróis e o dia da vitória final da Batalha de Guararapes é transformado em data celebrada como dia do Exército Brasileiro, sendo esta vista como o momento em que o exército foi fundado.

É justamente através de heróis, mitos, lendas, símbolos e celebrações que são criados que a identidade nacional é forjada - literalmente. Por isso, Benedict Anderson (1983) diz que a identidade nacional é "uma comunidade imaginada". Em outras palavras, a cultura nacional, segundo Hall (2006) são discursos, ou seja, narrativas, nos quais é apresentado ao povo um pacote completo, contento heróis para se orgulhar e ter modelos para seguir; mitos para não serem desmistificados; tradições e datas (Dia de Tiradentes, da Independência, Proclamação da

\footnotetext{
${ }^{2}$ Esta é a proposta de identidade elaborada quase três séculos mais tarde por Gilberto Freyre.
} 
República) para serem lembradas; símbolos (bandeira, hino e brasões nacionais) para serem venerados; uma língua comum para se comunicar e deixar escritas suas memórias; contos e narrativas populares para partilhar experiências passadas e míticas; cultura popular (folclore, carnaval) para lembrar o povo sua identidade e para que todos possam se expressar e se divertirem; religião ou religiões e santos para que o povo possa expressar sua fé e ter modelos para seguir; "alta cultura" (música, literatura, teatro, pintura) para que a nação seja "respeitada"; gastronomia (pratos próprios e exclusivos) para reforçar a identidade do povo; mito fundacional e ênfase nas origens para lembrar os difíceis tempos de outrora ou da conquista da liberdade (sacrifício de Tiradentes para conquistar a independência). E assim, esta lista poderia estender-se por páginas, todavia, o importante é destacar que este "pacote" de cultura nacional é crucial para que o povo possa se identificar e ter um sentimento de pertença a esta nação e, se possível, poder ufanar-se dela.

O mais elementar na construção de uma cultura nacional é possuir um herói libertador. Simón Bolívar foi consagrado herói-mito-libertador em várias nações sul-americanas, sendo que em algumas delas ele nunca esteve, mas, mesmo assim, ele foi elevado à categoria de herói nacional pela ausência de algum outro autóctone. No caso do Brasil, Tiradentes foi sagrado herói nacional somente depois da proclamação da República por necessidade de justificar a deposição do Imperador D. Pedro II, de certa maneira ainda considerado um estrangeiro que governava o Brasil. Tiradentes era o elemento local que faltava para o brasil ser Brasil. Convém lembrar que nosso "mártir da independência" não portou influência moral alguma à época que antecedeu e sucedeu a independência do Brasil.

Se falta algum desses elementos, cria-se - como sempre se fez na história da humanidade. A própria Inglaterra criou seu mito fundacional, para justificar a origem da nação inglesa. E se ainda falta nacionalismo ou algum outro elemento para unir o povo, "inventa-se" um inimigo externo comum. Dessa maneira, o povo é facilmente unido e é capaz de dar apoio ao pior dos ditadores.

Contudo, segundo Ernst Renan (1990, p. 19), o princípio espiritual da unidade de uma nação constitui na posse em comum de um rico legado de memórias, no desejo de viver em conjunto e na vontade de perpetuar, de uma forma indivisível, a herança que se recebeu.

Renato Ortiz (1994), por sua vez, argumenta que o modelo de identidade nacional, criado no final do século XIX pela geração de 1870 (embasado na "raça" e no meio geográfico), teria desenvolvido em nós brasileiros um sentimento de desagrado pela própria identidade, isto 
porque, enquanto em outros países a identidade nacional fora construída tendo como referência à superioridade do povo, o passado esplêndido ou a língua; no Brasil, um dos modelos de identificação pressupunha a "raça" que na época era considerada inferior e o clima que gerava pessoas indolentes e pouco propensas ao trabalho e à racionalidade, prevalecendo, segundo Sérgio Buarque de Holanda (1936) a cordialidade e os laços de família e simpatia.

Nossa identidade fora, dessarte, construída em bases consideradas negativas, o que teria gerado em nós, segundo Darcy Ribeiro e Bresciani, o sentimento de incompletude: "[...] o povo brasileiro seria ainda um por vir a ser, sempre colocado no futuro, um projeto, [...] homens e mulheres inacabados." (BRESCIANI, 2007, pág.12, In: ANDRADE, 2010), ou ainda, conforme celebremente posto por Stefan Zweig (1941), "um país do futuro".

Conquanto, Ortiz relança o debate sobre a busca da identidade nacional. Para o autor, esse não é o verdadeiro debate. E ele o reintroduz pelo seu reverso:

[...] a procura de uma "identidade brasileira" ou de uma "memória" brasileira que seja sua essência verdadeira é um falso problema. [...] a pergunta fundamental seria: quem é o artífice desta identidade e desta memória que se querem nacionais? A que grupos sociais elas se vinculam e a que interesses elas servem? (ORTIZ, 1994, p. 139)

Tal advertência é crucial ao se estudar a identidade nacional e a formação desta identidade. Há de se manter uma postura intelectual crítica para perceber que, na maior parte das vezes, o povo é transformado em massa de manobra com a finalidade de representar e defender interesses de um grupo. A massa é condicionada pelos meios de comunicação - fenômeno típico dos tempos hodiernos -, por meio da apresentação e representação das notícias ou da realidade a partir de um ponto de vista de seu interesse, a pensar e a agir de tal maneira, conforme sua agenda, vantagens e conveniências.

Em suma, são múltiplos os elementos da cultura nacional que constroem uma identidade nacional. E através do crivo da análise sócio-historiográfica facilmente percebe-se que a máxima de Anderson (que uma nação é "uma comunidade imaginada") é sobejamente verdadeira. Portanto, identidade nacional é tudo aquilo que distingue um povo de outro, que pode ser suas experiências, seus traumas, seu idioma, suas culturas, em síntese, tudo o que dá significado a um povo.

A seguir, nos detemos nos autores que pensam que a identidade nacional brasileira deve ser forjada a partir de um Estado forte e centralizador. 


\section{O PENSAMENTO AUTORITÁRIO BRASILEIRO}

Por advogar um Estado forte, que primasse pela centralização do poder e a imposição da lei e da ordem em todo o território nacional, diversos autores são categorizados no rol do pensamento autoritário brasileiro. Fazem parte desse elenco: Alberto Torres, Oliveira Viana, Oliveira do Amaral e Francisco Campos. Iremos, contudo, nos ater apenas nos dois primeiros autores. Suas obras seminais são citadas na sequencia de seus nomes, bem como o ano de sua primeira publicação.

\section{Alberto Torres (1865-1917): O Problema Nacional (1914) e A Organização Nacional (1914)}

Esse autor discute a desorganização e a identidade nacional; critica o modelo de federalismo adotado no Brasil (modelo federalista dos EUA sem os devidos ajustes, segundo o autor) e a importação de instituições políticas incompatíveis com nossa realidade.

Torres afirma que o caráter nacional foi formado por sua colonização, a escravidão e a indolência (vícios, corrupção...); defende o papel fundamental do Estado na construção da nação e na organização nacional em função das mazelas do regime político da República Velha: oligarquias, coronelismo, atraso, entre outros, que são frutos de nossa desorganização. Defende, portanto, reorganizar a Sociedade via intervenção do Estado, pois só este tinha condições de conduzir programas de âmbito nacional.

Em "A Organização Nacional" recomenda revisar a Constituição de 1891, propondo o fortalecimento da União e o enfraquecimento dos estados federados. Essa Constituição não permite a instalação de um Estado legal-burocrático weberiano. O Estado, a partir da esfera federal, deveria organizar o país, segundo Torres.

Para esse autor, o federalismo com sua descentralização vigente à época, na qual os estados tinham mais autonomia, desvirtuou-se no coronelismo, no qual os municípios são dominados por interesses privados na ausência do Estado nacional. Neste caso, havia uma aliança entre coronéis (lideranças locais) e governadores.

$\mathrm{Na}$ obra de Torres é patente a ausência da temática democrática. No pensamento autoritário, o Estado via a Sociedade como amorfa, incapaz de se organizar. Pensa o Estado nacional como espaço forte, sem cidadania e sem educação para as massas. Era um Estado 
excludente, mas protetor, com concentração de renda e exclusão social. Essas convicções de Torres foram incorporadas na vida política por Getúlio Vargas.

A era Vargas caracterizou-se pela preocupação de construção da Nação, forte e unificada. E o projeto de unificação da Nação, ora fragmentada, tinha na escola o seu grande vetor de propagação da cultura nacional e o civismo, principalmente com o uso exclusivo da língua portuguesa. Tenta-se, por decreto do governo Vargas, extinguir os guetos de imigrantes e trazê-los à integração.

O discurso de Alberto Torres sobre os imigrantes exalta o espírito empreendedor apenas dos alemães, excluindo outras etnias e os negros. A elite política brasileira queria o imigrante para povoar, embranquecer a população e produzir. Os imigrantes, por sua vez, queriam reproduzir um pedaço de seu país de origem em solo brasileiro.

Oliveira Vianna (1883-1951): Populações Meridionais do Brasil: populações do centro-sul (1920), Evolução do povo brasileiro (1923)

Segundo Ricupero (2008), este autor é racista e autoritário; reflete o reacionarismo da classe dominante brasileira da época, o pensamento autoritário da Velha República e conservador do Império.

Oliveira Vianna, influenciado pela Escola de Sociologia de Fréderic Le Play, elaborou a construção de tipos regionais com base em fatos sociais ("populações rurais do centro-sul"). Do mesmo modo, influenciado pela Psicologia Social de Gustave Le Bom, obsorveu a ideia da existência de alma da raça ou caráter nacional: as raças não se distinguem tanto pelas características físicas, mas pelos traços psicológicos, havendo uma hierarquia entre elas. Assim, justificava-se que era possível 60 mil ingleses dominar 250 milhões de indianos durante o período colonial sobre a Índia.

Em Evolução do povo brasileiro, Oliveira Vianna aceita a crença no protagonismo da raça ariana (ideias da Antropologia Física de Vacher de Lapouge). O autor também critica a constituição da Velha República (de 1891): “idealismo utópico ou constitucional” pelo fato de os liberais desejarem adotar instituições estrangeiras sem mostrarem preocupação em adequar às condições brasileiras. Para ele, medidas como a descentralização, ao invés de gerarem o self-government à americana, favoreceriam o poder dos caudilhos. 
Objetivo de sua obra, segundo Ricupero (2008), seria o de "ressaltar o quanto somos distintos dos outros povos". Critica também a elite intelectual por absorver as ideias norteamericanas e europeias.

Neste sucinto apanhado verificamos que tanto Alberto Torres quanto Oliveira Viana são caracterizados como autores do pensamento autoritário brasileiro porque defendiam um Estado centralizador e forte, e que esse Estado possuísse uma administração centralizadora e de alcance nacional, coibindo o poder dos coronéis locais. Do mesmo modo, rechaçavam as ideias da política liberal vindas dos Estados Unidos e da Europa, pois o Brasil, devido suas características sui generis (povo, escravatura, clima e relevo) não estava pronto para absorver e implementar tais ideias.

Tanto Alberto Torres quanto Oliveira Viana, e mais adiante veremos também em Nestor Duarte, concordam que "não temos um povo". Para explicar o Brasil e sua identidade tem-se que recorrer ao seu passado sem a formação de um povo. Também não se consegue explicar no Brasil a formação de uma burguesia e proletariado, conforme postula Oliveira Viana. Ou seja, não temos povo porque não temos formação de classes, não há uma sociedade orgânica (há uma “inorganicidade"). Não há uma coesão nacional; há uma sociedade sem laços de solidariedade.

A inorganicidade, segundo esses autores, provém de vários fatores: importação de instituições sem levar em conta nossa realidade que é a de um país com riquezas naturais que não são exploradas racionalmente, predominância étnica com negros e mestiços, características coloniais (grandes fazendas com mão de obra escrava), dimensões continentais, fragilidade do Estado no Brasil e falta de consciência cívica nacional. Países colonizados demandam um Estado com papel mais ativo para organizar a sociedade e a criação de um povo.

Passaremos, a seguir, a uma sucinta análise da contribuição de outros autores clássicos conhecidos como intérpretes do Brasil.

\section{INTÉPRETES DO BRASIL}

Nesta secção nos detemos sobre os outros autores considerados clássicos intérpretes do Brasil no âmbito político, social e econômico. São autores que nos ajudam a compreender e explicar o funcionamento das instituições, relações sociopolítico-econômicas, enfim o funcionamento da Sociedade e do Estado brasileiro. Não são abordadas todas as obras desses 
autores, mas apenas aquelas que julgamos mais significativas para este estudo, que tem como seu fio condutor a compreensão da identidade brasileira. Da mesma forma, as obras mencionadas não são expostas em profundidade, apenas alguns elementos são destacados. Nesta secção abordamos Gilberto Freyre, Sérgio Buarque de Holanda, Raymundo Faoro e Florestan Fernandes.

\section{Gilberto Freyre (1900-1987): Casa-Grande e Senzala (1933)}

Gilberto Freyre busca um mito explicativo para o Brasil e brasileiros e apresenta uma visão otimista do país. Para esse autor, a identidade brasileira está na miscigenação das raças: branco, negro e índio. Freyre destaca a primazia da família na colonização através do patriarcalismo; latifúndio e patriarcalismo são os fatos empírico-teóricos que dão unidade ao Brasil: a casa grande seria um pequeno mundo autossuficiente. $O$ autor avalia que a miscigenação já vinha de Portugal com o exemplo dos mouros e judeus. E aconteceu no Brasil uma adaptação luso-tropical.

Segundo Jessé Souza (2010), Freyre interpreta e dá significado ao encontro das raças e culturas como resposta ao racismo que imperava na década de 1920. A mestiçagem era considerada como raça inferior, não tendo as qualidades dos brancos, nem dos negros puros (que era o caso nos Estados Unidos). Raça ganha, em Freyre, o significado de cultura e o encontro cultural passa a ser uma virtude nacional. Sabe que o Brasil não pode competir com os Estados Unidos em racionalidade e produtividade, por isso, Freyre ressalta as virtudes da prémodernidade: cordialidade, sentimento e calor humano. Ele constrói esse mito em contraposição à modernidade do mundo desenvolvido: a "emocionalidade" versus a racionalidade, ou seja, o que os EUA não sabem fazer: a integração racial, uma singularidade absoluta brasileira. (SOUZA, 2010).

Dessa forma, Casa Grande e Senzala influencia a intelectualidade brasileira e ganha o mundo com o mito da democracia racial. Esse mito foi erguido por meio de uma história convincente, ia ao encontro dos interesses de Getúlio Vargas que promoveu o carnaval no Rio de Janeiro, onde se ensinava esse mito nas escolas. E, assim, tornou-se leitura sociológica do Brasil.

Florestan Fernandes e Roger Bastide, por sua vez, nas décadas de 1950-60 trabalham para desmitificar a ideologia da democracia racial contida na obra de Freyre. Para estes, tratava-se de um convívio pretensamente harmonioso entre brancos, negros e índios, mas era, sobretudo, regido por relações de poder. 
Carlos Guilherme Mota problematiza a obra de Freyre e identifica nela uma verdadeira cristalização da ideologia da cultura brasileira; sugere a existência de um caráter brasileiro que eclipsaria "as contradições de classe, e mesmo de raça." (MOTA, 1990, p. 47)

\section{Sérgio Buarque de Holanda (1902-1982): Raízes do Brasil (1936)}

Buarque de Holanda apresenta uma visão otimista, liberal-conservadora e weberiana sobre o Brasil. Estudou em Berlim e trouxe as ideias do tipo-ideal de poder burocrático, no qual deveria ser regido pela impessoalidade, competência técnica e meritocracia, separação entre propriedade e administração, com o fim de racionalizar e otimizar a atuação do Estado, ancorado na formalização, divisão do trabalho e hierarquia. (WEBER, 2002).

O autor realiza sua análise contrastando os princípios de burocracia de Max Weber e de democracia propostos por Jeremy Bentham (1979), regido pelo princípio da "maior felicidade para o maior número de pessoas", com a realidade brasileira. Em primeiro lugar, ressalta o tradicional personalismo, do qual provem a frouxidão das instituições e a falta de coesão social, além da ausência do princípio de hierarquia e a exaltação do prestígio pessoal com relação ao privilégio. (RICUPERO, 2008).

Com respeito à família patriarcal, conceito central em Freyre, Holanda identifica na família o único setor da vida brasileira cuja autoridade, a do pai, não fora questionada. Contudo, essa autoridade do patriarca ultrapassava a esfera doméstica e estendia-se ao domínio público, não respeitando a hierarquia das instituições estabelecidas, o que, para o autor, tratava-se de "uma invasão do público pelo privado". (HOLANDA, 2004, p. 89). Este comportamento patriarcal e personalista, segundo Holanda, dificultaria o estabelecimento do Estado democrático e mesmo de qualquer Estado no Brasil, sendo contrário ao princípio básico da democracia liberal de Bentham e de burocracia de Weber.

Para Holanda, a família segue o princípio do amor e "amar alguém é amá-lo mais do que aos outros" (Ibd., p. 156). Esta parcialidade que o meio doméstico estimula, seria incompatível com a atitude imparcial diante dos cidadãos, implícita na democracia liberal. Há oposição entre privilégios pessoais e exigências abstratas, que se materializa pelo funcionário patrimonial versus o puro burocrata.

Seu principal conceito na obra é o de "homem cordial". Este homem é regido pelo coração, ou seja, pelos sentimentos de o amor e ódio: homens que obedecem aos imperativos do 
coração e não as normas impessoais e abstratas, sendo, assim, muito difícil de estabelecer ordem pública e democracia. (RICUPERO, 2008, p. 115).

Antônio Cândido, no Prefácio de Raízes do Brasil de 1967, assim define o "homem cordial" de Buarque de Holanda:

Formado nos quadros da estrutura familiar, o brasileiro recebeu o peso das 'relações de simpatia', que dificultam a incorporação normal de outros agrupamentos. Por isso, não acha agradáveis as relações impessoais, características do Estado, procurando reduzi-las ao padrão pessoal e afetivo. Onde pese a família, sobretudo em seu molde tradicional, dificilmente se forma a sociedade urbana de tipo moderno. [...] 0 'homem cordial' não pressupõe bondade, mas somente o predomínio dos comportamentos de aparência afetiva, inclusive suas manifestações externas, não necessariamente sinceras nem profundas, que se opõem aos ritualismos da polidez. (CANDIDO, 1967, p. 16-17).

Por sua vez, o próprio autor assim define seu conceito: "Um traço definido do caráter brasileiro, no qual permanece ativa e fecunda a influência ancestral dos padrões de convívio humano, informados no meio rural e patriarcal." (HOLANDA, 2004, p. 146-7). O homem cordial tem dificuldade para compreender a distinção fundamental entre os domínios do privado e do público, por isso, é patrimonialista, preferindo o favoritismo e o "jeitinho", tendo aversão à impessoalidade, tem dificuldade de viver só, pois o convívio social o liberta.

No domínio linguístico há forte presença do diminutivo (-inho) e a omissão do nome de família no trato. "Homem cordial" ficou associado à concepção do brasileiro típico, como gentil, hospitaleiro e pacífico, mas o autor alerta para as consequências negativas quando se refere ao trato da coisa pública. Neste sentido, o pesquisador Bernardo Ricupero afirma: "Sérgio Buarque de Holanda considera que as relações pessoa a pessoa, primárias, criam empecilhos para se ter uma ordem social mais impessoal e racional e, ainda mais sério, para a constituição de uma democracia no país." (RICUPERO, 2008, p. 122).

A partir do acontecimento da Abolição, Sérgio Buarque vê uma certa compatibilidade entre a democracia e a formação social brasileira, incluindo a hierarquia racional. Contudo, critica o pensamento autoritário de Alberto Torres e Oliveira Vianna: "O despotismo condiz mal com a doçura de nosso gênio." (HOLANDA, 2004, p. 142)

Raymundo Faoro (1925-2003): Os donos do poder: a formação do patronato brasileiro (1958)

Raymundo Faoro analisa as origens da corrupção, da burocracia e do estamento burocrático brasileiro a partir da formação do Estado nacional português, de onde foi transposto a 
estrutura e o modo de funcionamento do Estado brasileiro. Usa conceitos weberianos, como estamento e burocracia e ressalta que o Estado patrimonialista estamental está presente na origem de nossa formação política, ou seja, desde os primórdios de Portugal. Em sua obra demonstra que é o tipo de Estado que define o tipo de elite.

Portugal, o primeiro Estado-nação europeu, já nasce e se constitui como Estado patrimonialista, no qual o rei detém a maior parte das terras e não separa os seus negócios privados e os do Estado. O rei controla a atividade econômica e dá concessões para quem deseja realizar atividades comerciais e concede terras (capitanias, sesmarias) com controle centralizado das atividades econômicas, o que se diferencia de uma sociedade feudal. Assim, o Brasil se constitui, em sua identidade, desde os primórdios, sob o domínio patrimonialista.

Conforme Faoro, o que se forma deste patrimonialismo é o estamento: uma camada social formada por indivíduos que possuem funções a executar dadas pelo rei. Não é classe, nem elite política, mas uma burocracia estamental, formada por aqueles que administram e cobram impostos. Desse modo, não se formou no Brasil um capitalismo moderno, mas um capitalismo político, no qual o Estado (o rei) controlava as atividades econômicas.

Somente a partir da industrialização dos anos de 1930, o Estado se torna responsável por identificar as necessidades de infraestrutura, bem como buscar recursos. O Estado também se torna empresário com a criação da CSN e da Petrobrás. Contudo, o capitalismo de Estado (ou capitalismo político) é incompatível com o capitalismo moderno, segundo Faoro.

Com relação à burocracia moderna weberiana, a gestão sai da mão dos indivíduos privados e passa a uma burocracia desligada dos interesses privados. Faoro afirma que em Portugal e no Brasil não houve esta separação, mesmo com o processo de industrialização dos anos de 1930.

O estamento não é homogêneo e não é uma camada homogênea: são pessoas recrutadas pelo rei de diferentes classes. O que elas têm em comum é a lealdade ao rei e a honra. $\mathrm{O}$ estamento tem interesse próprio, que é o aumento das rendas. Estas são repassadas ao rei e parte permanece com seus membros; é uma camada social que se alimenta do Estado patrimonialista.

Como o estamento não é homogêneo em termos de classe, o Estado não representa os interesses de uma classe, para o autor. O Estado não é controlado por uma classe ou ordem privada, nem consegue alcançar autonomia. Não obstante, o Estado é maior e se sobrepõe à sociedade, dificultando a formação de classes. 
O Brasil, para Faoro, conviveu com um Estado patrimonialista estamental (em detrimento ao desenvolvimento de classes e da democracia), tendo caráter autoritário e monopolizador do poder político, impossibilitando o aparecimento de uma verdadeira democracia, mas possibilitando o aparecimento de líderes populistas que dominaram as massas ao seu interesse.

\section{Florestan Fernandes: A revolução burguesa no Brasil (1974)}

A grande questão para Florestan (já posta em suas obras anteriores) é a democracia numa sociedade capitalista e na obra em tela, ele se propõe a estudar o "modelo autocrático burguês de desenvolvimento capitalista" no Brasil a partir de dois níveis: estrutural (dependência externa ou capitalismo dependente, numa dupla articulação: interna e externa) e histórico (a realidade concreta viva pelos agentes políticos, econômicos e sociais ou seja, "a realização efetiva das relações de classe"). Este modelo, conforme explica o autor, se apropria de elementos arcaicos, transportando o passado ao presente: "a ordem social moderna no Brasil não é democrática e aberta senão para alguns; ou seja, a burguesia não realiza a revolução burguesa, não universaliza a igualdade." (Fernandes, 1976, p. 168). E continua (já ao final de sua obra):

As classes burguesas não querem (e não podem, sem destruir-se) abrir mão: das próprias vantagens e privilégios; dos controles de que dispõem sobre si mesmas, como e enquanto classes; e dos controles de que dispõem sobre as classes operárias, as massas populares e as bases nacionais das estruturas de poder; As vantagens e privilégios estão na raiz de tudo, pois se as classes burguesas realmente "abrissem" a ordem econômica, social e política perderiam, de uma vez, qualquer possibilidade de manter o capitalismo e preservar a intima associação existente entre dominação burguesa e monopolização do poder estatal pelos estratos hegemônicos da burguesia. (lbd., p. 363-4).

Em Florestan Fernandes descortinamos que uma nação não aparece ou não se forma de uma hora para outra; ela se constitui lentamente, numa trajetória de zigue-zagues (ibd., p. 27), por isso justifica-se sua análise de longa escala, a partir do Brasil Colônia, para se ter condições de compreender o Brasil hodierno. $\mathrm{O}$ autor aponta quatro fatores constitutivos das transformações ocorridas no Brasil:

(i) de caráter histórico e através de um processo político: as implicações socioeconômicas da Independência, que foi a primeira grande revolução social que se operou no Brasil, pois marca o fim da era colonial e o início da sociedade nacional (ibd., p. 31), bem como a absorção das ideias liberais pela elite naquilo que Ihes interessava. Contudo, não chega a constituir-se num processo 
revolucionário, pois houve apenas mudança no estatuto jurídico-político e nada modificando seu substrato material, social e moral, incluindo a manutenção do sistema escravista, que iria se perpetuar até a consolidação do fazendeiro de café e o surgimento do imigrante, pois os agentes burgueses organizam-se mais como estamentos do que como classe.

(ii e iii) dois tipos humanos: o fazendeiro de café e o imigrante, figuras centrais das grandes transformações dos panoramas socioeconômico e político, marca também a introdução do trabalho assalariado.

(iv) um processo econômico: "mudanças do padrão de relação dos capitais internacionais com a organização da economia interna" (ibd., p. 30), constituindo um capitalismo dependente.

Na sua análise, Florestan esclarece que no Império e na República a Sociedade civil ficara subsumida aos estamentos sociais dominantes, ou estamentos senhoriais. A maior parte da população excluída da sociedade civil. O domínio senhorial, isolado no período colonial, alcança o poder político na Monarquia constitucional e na República. (ibd., p. 40). Com a Independência acontece a passagem da sociedade colonial à nacional sob a influência do liberalismo, com suas palavras de ordem: "liberdade", "igualdade", "progresso", "opinião pública", o que causa problema e desequilíbrio, pois a elite conservadora no poder, o estamento dominante e a ordem legal instituída (Constituição) sob o modelo ideal de um Estado nacional liberal, resultou num Estado reduzido à condição de cativo da sociedade civil e o governo em meio de dominação estamental. (ibd., p. 44).

Esses processos histórico-político-sociais trazem à tona a ordem econômica competitiva, mas não desimpediram inteiramente as potencialidades da racionalidade burguesa, caracterizado pela coexistência do arcaico com o moderno ou pelo processo que o autor chama de "capitalismo dependente", i.e., associação da burguesia com o capital internacional, bem como a monopolização do Estado pela burguesia estaria, para Florestan, na base do modelo autocrático, que ele chama de "democracia restrita" que marca o século XX brasileiro. A revolução burguesa, portanto, acontece de forma parcial: transformação do capitalismo, mas não uma revolução nacional e democrática, não havendo ruptura com o passado.

A revolução burguesa assumiu, portanto, uma forma conservadora, a partir de uma coalizão entre as elites modernas e as tradicionais. Para o autor, a democracia é intrínseca à própria natureza do capitalismo e se a elite capitalista nacional não realiza a democracia moderna, então passa a ser do operariado a missão da sua realização. 
A conviç̧ão de Fernandes sobre a não abertura universal da igualdade vem-se formando desde sua obra A integração do negro na sociedade de classes de 1964, na qual revela sua descrença no que diz respeito à suplantação da marginalização social do negro. Para o autor, impera a ausência de direitos fora dos setores sociais dominantes.

A seguir, ampliamos o leque de autores e abordamos outros que deram seu aporte valioso para compreender o Brasil e desnudaram sua identidade sendo forjada na dura realidade dos fenômenos políticos e sociais.

\section{OUTROS INTÉRPRETES DO BRASIL}

Nesta parte abordamos outros autores que deram uma contribuição no âmbito sociopolítico para compreender e explicar o funcionamento das instituições, relações sociopolítico-econômicas, enfim o funcionamento da Sociedade e do Estado brasileiro. Não são mencionadas todas as obras desses autores, mas apenas aquelas que julgamos mais significativas para este estudo que tem como seu fio condutor a compreensão da identidade brasileira. Da mesma forma, como anteriormente, as obras mencionadas não são expostas em profundidade, apenas alguns elementos são destacados. A pluralidade dos autores e seus temas de estudo justificam-se pela intenção proposital de aportar a esse estudo a complexidade da realidade brasileira e da formação de sua identidade. A diversidade desses autores proporciona uma melhor, mais adequada e rica compreensão do Brasil. Nessa secção destacamos Nestor Duarte, Victor Nunes Leal, Gláucio Soares, Simon Schwartzmann e Jessé Souza.

Nestor Duarte (1902-1970): Ordem privada e organização política (1939) e Reforma Agrária (1953)

Nestor Duarte, contrariamente a Faoro, sustenta que o Brasil tinha características feudais e como resultado do nosso feudalismo não houve desenvolvimento de um povo político no país. Este autor entende povo político como identidade de consciência política, cidadania, educação e experiência histórica. A educação formal, para Duarte, teria condições para desenvolver a noção 
de povo político, mas também seria necessária a experiência histórica, que seria a participação em revoluções e em reivindicações políticas, tendo o povo como parte ativa.

O autor ressalta que o principal fator para que não houvesse povo político foi o predomínio da ordem privada sobre o político, incluindo predomínio da grande propriedade sobre o Estado. 0 Estado é fragilizado por sua captura pela ordem privada, se conformando aos interesses desta. Nesta ordem, a família extensa também tinha seu papel, sendo suas funções, além de ser procriadora (o que possibilitou a autonomia ao proprietário rural pela geração de mão-de-obra), exercia funções política e econômica.

Com relação à reforma agrária, tema de sua segunda obra, o autor averigua que a grande propriedade persiste na República Velha, mantendo o poder dos grandes proprietários rurais da época do Império. Se a reforma agrária tivesse sido realizada após a Independência, o resultado e o desenvolvimento teriam sido outros. (DUARTE, 1953)

Duarte previu a reforma agrária para terras próximas aos centros urbanos. As casas não deveriam ficar isoladas ou dispersas, mas em vilas para que houvesse socialização, solidariedade e a formação do povo político. Neste sentido, mais tarde Osnir Dombrowski (1998) e José Murilo de Carvalho (2000) irão observar que houve transposição da família portuguesa ao Brasil, fenômeno que estes autores chamam de Iberismo: um povo pouco afeito às atividades políticas, povo particularista (muito centrado no seu próprio interesse), comunal e fragmentado. Isto explica, segundo esses autores, o isolamento das propriedades e a falta de laços ou comunicação entre as propriedades. Acrescentamos que estas características certamente contribuíram para a não formação de um povo político.

Nestor Duarte pergunta-se porque não há no Brasil cidadania como na França ou Inglaterra. Responde que é pelo fato do predomínio da ordem privada sobre o público que fortalece a família. A propriedade era passada do pai ao filho primogênito sem haver divisão. A predominância da ordem privada não permitiu o estabelecimento de uma classe média, havendo pouco mais que senhores e escravos. A classe média não se forma pelo modelo de grande propriedade que não estabelece os trabalhadores na propriedade; estes são quase que nômades.

Victor Nunes Leal (1914-1985): Coronelismo, enxada e voto (1949)

Para Victor Nunes Leal, o coronelismo - fenômeno fundamental para compreender a identidade político-social brasileira, especialmente no que tange a subserviência e a subcidadania - 
é típico da República Velha (1889-1930) e "é o resultado de uma combinação entre o arcaico e o moderno do processo histórico brasileiro." (2012, p. 43). Trata-se de um tipo de relação de dependência entre coronéis e trabalhadores rurais, fenômeno que se explica dentro da política dos governadores e descentralização aportada pela constituição de 1891. Esta traz duas mudanças importantes: (i) As atribuições dos municípios: maior autonomia em detrimento da união; os municípios passam a ter maiores atribuições, mas com os mesmos recursos. Nestas condições, aumenta-se a importância dos chefes locais (coronéis) junto à população e junto ao governador (se for do mesmo partido). (ii) Os trabalhadores rurais passam a ter direito de voto e, com isso, tornam-se massa de manobra no jogo político. Os trabalhadores rurais não dão importância ao voto, pois sabem que seu voto não modifica nada.

Na prática, os municípios vivem uma autonomia extralegal: recursos são apropriados pelos mandatários e, por vezes, utilizados para fins eleitorais. São os coronéis que mobilizam "seus rebanhos eleitorais". Os coronéis vão buscar "seus eleitores" nas fazendas e fornecem transporte, alimentação e eventualmente hospedagem e vestimentas. Fazem uso de recursos públicos, com a construção de obras (estradas, pontes...) e a manipulação eleitoral.

O voto não era secreto e o coronel exerce poder discricionário sobre a vida dessas pessoas. O voto universal representa uma incerteza no resultado do processo eleitoral. Para trazer de volta a certeza ao processo, "trava-se" a cidadania. Nesse contexto, o voto é estratégico, pois a quantidade de voto dá uma medida do poder do coronel e este os usa como poder de barganha. Assim, na camada inferior há uma relação de dominação e na camada superior, das elites políticas, há uma relação de negociação. O voto não é importante para a camada inferior, pois quem ele vota não o representa, de acordo com esse sistema de coronelismo.

O coronelismo é um sistema de reciprocidade, no qual os coronéis (nível local) dão apoio ao governador e este ao presidente. Do mesmo modo, o presidente da República precisa do apoio do governador e este depende do apoio dos coronéis locais. O governador não consegue ganhar uma eleição ou fazer algo nos municípios sem passar pelos coronéis. Os coronéis usam os votos da população que têm para negociar poder, verbas e recursos junto aos governadores. O coronel é o benfeitor destes indivíduos, pois presta serviços: providencia consulta médica, empresta dinheiro, obtém crédito, entre outras benesses. Assim, o coronel preenche funções que deveriam ser realizadas pelo poder público, mas que não existem pelo fato da "rarefação do poder público". Portanto, é natural votar no candidato que o coronel indicar. 
$\mathrm{Na}$ medida em que prevalece a grande propriedade e o isolamento, persiste a força do coronel. Contudo, o aparecimento do rádio quebra aos poucos este isolamento. Mesmo com a decadência econômica das grandes propriedades e com a industrialização a partir dos anos 1930, o poder dos coronéis permanece, pois a grande propriedade continua indivisível.

Geralmente os coronéis são grandes proprietários rurais decadentes. A decadência econômica dos coronéis leva-os a uma sobrevida através da manipulação política. Apesar de decadentes, estes são vistos ainda como "ricos" pela população pobre e trabalhadores rurais. 0 coronelismo é um sistema de dominação dupla: do governador sobre o coronel e do coronel sobre os colonos, meeiros, parceiros e pequeno proprietário.

O coronelismo, numa interpretação sociológica weberiana, é um fenômeno de liderança política tradicional que envolve barganha e liderança. Na medida em que o Estado se moderniza, o coronelismo tende a acabar. Quando as relações se modernizam, há uma estrutura de classes mais sofisticadas e menos espaço aos "favores" na política. Assim, a obra de Victor Nunes Leal é peçachave para interpretar o Brasil e sua evolução sociopolítica e econômica.

\section{Gláucio Ary Dillon Soares: A Democracia Interrompida (2001)}

A obra de Gláucio Soares é peça importante para estudar o fenômeno da autoridade no desenvolvimento sociopolítico brasileiro e compreender o caráter identitário de submissão fatalística do povo brasileiro do interior com pouca educação formal. Selecionamos algumas passagens de sua obra na qual o autor distingue duas dimensões da autoridade tradicional weberiana:

(i) A autoridade tradicional na sua dimensão sagrada. Segundo Weber:

A autoridade tradicional se baseia na fé na natureza sagrada da ordem social e de suas prerrogativas como existiam nos tempos de outrora. A autoridade patriarcal representa seu tipo puro. O corpo político é baseado em relações comuns: o homem que domina é o 'senhor' que governa 'súditos' obedientes. 0 povo obedece ao senhor pessoalmente, pois, tradicionalmente, sua dignidade é reverenciada; a obediência baseia-se na devoção. As ordens são essencialmente impostas pela tradição.

O sistema de autoridade na política do atraso se encaixa nessa descrição. Tanto a ordem social como o direito não questionado dos proprietários à propriedade, ao status, à autoridade e ao poder demonstram isso. A Igreja, obviamente, não apoiava a ordem existente per se, mas contribuía para a sua manutenção pela sua forte oposição a ideologias que pudessem causar mudanças revolucionárias ou qualquer espécie de mudança radical. (SOARES, 2001, pp. 276-277) 
(ii) A autoridade tradicional na sua dimensão sagrada e de fatalismo:

O sistema social tradicional - do qual a Igreja, antes do Vaticano II, era parte cooptava os membros das classes dominantes por meio de um simbolismo paternalista. O proprietário tinha, frequentemente, funções paternalistas; batizava os filhos dos lavradores e, como padrinho, dava recompensas "extras" ao lavrador. Este tinha um nível tão baixo de aspirações que ficava profundamente agradecido e sentia-se devedor quando sua filha pequena recebia uma boneca do homem que Ihe pagava menos do que o salário mínimo; considerava a pobreza um fato natural e não tinha nenhuma aspiração maior. F.P.R., lavrador numa fazenda de Minas Gerais, estado incluído no Brasil subdesenvolvido, disse numa entrevista: "a genti tem qui trabaiá pruque bem mesmo a genti num fica, u qui farta é ficá velho, si Deus ajuda, u sinhô num acha qui tá certo? As veis tem genti qui ganha a sorte grande mas perde tudo".

E referindo-se a possibilidade de enganar o patrão, quando the perguntaram qual sua opinião sobre um bom trabalhador, o lavrador afirmou: "Enganá u patrão é mesmo qui enganá Deus, aqui eu tenho 14 anos, nunca dei bolo em ninguém, aprendi na isperiência e pelo poder de Deus. Os pobre tem qui ajudá u patrão, sinão eles é qui perde..." (Idem).

Esta narrativa, embora trágico-fatalista, é importante para ilustrar o vínculo do povo com seus patrões num ambiente sem a educação formal, marcado pela relação de dádiva, submissão, alienação, sem nenhuma consciência de povo, de justiça e de cidadania.

\section{Simon Schwartzman (1939-): Bases do Autoritarismo Brasileiro (1975)}

Simon Schwartzman não se refere ao regime político autoritário de 1964-85. Trata-se de uma análise de um padrão de relação política e de configuração de Estado e Sociedade no Brasil; não de uma disposição autoritária, mas refere-se ao padrão de relação política entre Estado e Sociedade brasileira. Neste sentido, segundo o autor, os industriais brasileiros não estabeleceram um projeto ou política de desenvolvimento industrial e não se preocupavam com o desenvolvimento nacional, ao contrário, dependiam dos favores particulares do governo e, a este, deveriam dar demonstrações contínuas de lealdade e apoio. (1975, p. 148)

O cerne de sua obra está em distinguir a matriz autoritária e a democrática. Na matriz autoritária, Schwartzman afirma que o Estado domina a sociedade. Nesta matriz, a sociedade deve ser una, inteira, sem conflitos. A sociedade não possui controle sobre a burocracia, esta ganha força. Já na matriz democrática, a sociedade possui conflitos, interesses e tem partidos. Há controle sobre a burocracia.

Segundo o autor, no Brasil não há representação, mas sim cooptação; logo, autoritarismo, sem a organização burocrático-legal-racional. Não há movimento da Sociedade para o Estado, mas 
do Estado para a Sociedade através do patrimonialismo. Há uma burocracia que é "dona" do Estado, um estamento burocrático que controla o Estado. A esfera pública está "colonizada" pelos interesses privados daqueles que controlam o Estado, ao contrário do que ensinou Weber. Para este, o que caracteriza o Estado moderno é a separação do público e privado.

\section{Jessé Souza (1950- ): A Construção Social da Subcidadania (2006)}

Jessé Souza estuda as sociedades periféricas e a exclusão social e investiga "A naturalização da desigualdade" e "As causas não econômicas da desigualdade social brasileira". As desigualdades e a violência já não chocam mais. Por isso, é oportuno o alerta de Souza sobre a naturalização das desigualdades, como se fossem normais tanta desigualdade ou que fossem frutos de relações socioeconômicas "justas", e sobre a pretensa harmonia e pacificação social que mascaram relações de dominação e violência.

O autor considera frágil a teoria que explica o Brasil e os brasileiros como personalismo e patrimonialismo, construída a partir do mito nacional de Gilberto Freyre (empregado politicamente por Getúlio Vargas) para que os brasileiros pudessem se perceber como um povo e que pudesse unir todos os brasileiros em torno destas características: caloroso, hospitaleiro, emotivo, enfim, uma democracia racial.

Todavia, Jessé Souza objeta que a crítica ao patrimonialismo ou à corrupção é uma crítica burguesa, pois não quer ver a estrutura de exclusão provocada pelo mercado. O patrimonialismo é uma justificativa perfeita, segundo o autor, pois coloca a culpa no Estado, tirando a responsabilidade de si e mesmo também a colocando nos excluídos que são incapazes de se integrarem numa economia capitalista de mercado. A classe capitalista dominante aprecia esta versão, que é diferente do conceito de patrimonialismo histórico e de burocracia de Weber, pois coloca todas as mazelas do Brasil no Estado e nos políticos, longe de si - em Brasília - para que suas consciências estejam tranquilas.

De Bourdieu, Souza busca resgatar principalmente a crítica à "naturalização" das relações sociais de dominação contida na teoria do habitus e sua ênfase no aspecto "automático" - caráter irrefletido - dos diferentes comportamentos sociais classificatórios:

É esse aparato também que permite a Bourdieu perceber dominação e desigualdade onde outros percebem harmonia e pacificação social. É isso que o faz fundamental para qualquer análise, seja das sociedades centrais ou periféricas, 
interessada em desvelar e reconstruir realidades petrificadas e naturalizadas. (SOUZA, 2006, p. 47).

Esse aspecto revela-se ainda mais decisivo quando pensamos no caráter central atribuído por Bourdieu ao mascaramento das precondições econômicas inerente ao exercício da dominação classista, ou seja, da dominação simbólica. E nesse particular, da própria ideologia da igualdade que serve de base ao consenso social e político ocidental - obscurecendo as relações de desigualdade. (BRAGA, 2004).

Assim, encerramos a apresentação das contribuições de alguns autores, num fluir histórico - sabedores que cometemos injustiça ao deixar de fora diversos outros, possivelmente, tão ou mais relevantes - para a compreensão do Brasil e sua identidade. Passamos, a seguir, às considerações finais.

\section{UMA SÍNTESE DO FLUXO DE IDEIAS E NARRATIVAS NA BUSCA DE UMA IDENTIDADE NACIONAL BRASILEIA}

Terminamos nosso périplo na tentativa de compreender o Brasil e sua identidade utilizando uma gama de autores, à primeira vista muito diversificados, nos quais pudemos observar os traços da identidade brasileira e de nossa constituição sociopolítica sendo forjados através do fluxo de nossa constituição sociopolítica e história.

Gostaríamos de retornar à Marilena Chauí, agora numa análise estritamente sociológica, que corrobora e robustece o que os diversos autores citados neste trabalho demonstraram: nossa identidade é construída a partir de relações desiguais, de privilégios para uns poucos e de construção de nação com fraca legitimidade, pois colonizada pelos interesses particulares e mantida por ideologias, reforçadas pela mídia de massa, escola e mesmo a religião.

Chauí, na perscruta de uma identidade, em Brasil: o mito fundador e sociedade autoritária, observa que a relação de dependência pode ser observada em todos os aspectos da sociedade brasileira, numa perspectiva histórica, deixando forte marca na constituição de sua identidade: 
Conservando as marcas da sociedade colonial escravista, ou aquilo que alguns estudiosos designam como 'cultura colonial', a sociedade brasileira é marcada pela estrutura hierárquica do espaço social que determina a forma de uma sociedade fortemente verticalizada em todos os seus aspectos: nela as relações sociais e intersubjetivas são sempre realizadas como relação entre um superior, que manda, e um inferior, que obedece. As diferenças e assimetrias são sempre transformadas em desigualdades que reforçam a relação mando-obediência. $O$ outro jamais é reconhecido como subjetividade nem como alteridade. (2000, p. 89).

Nessa trajetória, tornou-se patente que não há como separar identidade brasileira de sua constituição político-histórico-social e econômica. E tal é a justificativa de termos alargado o escopo de abrangência dos "intérpretes do Brasil" para compreender outros fenômenos importantes para a construção do conhecimento sobre o Brasil e a constituição da identidade brasileira, como a subalternidade, a subcidadania, o mando e a submissão, relações de dependência, desigualdade, passividade, fatalismo, familismo, cordialidade, entre outras qualificações que foram forjadas por meio do patrimonialismo, da dominação estamental, coronelismo, autoritarismo e autocracia, democracia restrita, capitalismo dependente, violência física e simbólica, exclusão, relações servis e de privilégios.

Nessa construção sócio-político-histórico da identidade brasileira, divisamos que Alberto Torres e Oliveira Vianna creditam nossa falta de identidade e o fato de não sermos um povo à nossa desorganização nacional, descentralização, cópia de instituições estrangeiras sem levar em conta nossas especificidades. Nessa mesma esteira, Nestor Duarte aponta a ausência de um povo político no Brasil, i.e., a inexistência de um povo com consciência política, educação e experiência histórica, devido ao predomínio da ordem privada sobre o político, fragilizando o Estado que é conformado aos interesses da ordem privada, ou seja, o patrimonialismo discutido por Faoro. Para este autor, a estrutura do Estado patrimonialista impossibilita o surgimento da democracia, mas possibilita o surgimento de líderes populistas, que constitui-se numa marca identitária da vida política brasileira.

Do mesmo modo, Sérgio Buarque de Holanda une o patrimonialismo ao "homem cordial" que por sua vez é conectado aos privilégios pessoais, amante do favoritismo, do "jeitinho" e avesso à impessoalidade, constituem fatores de impedimento da instalação de uma democracia moderna, isenta e sem favoritismo e com direitos iguais para todos. 0 patrimonialismo e o caráter de "homem cordial" favoreceram a construção dos laços familiares no trato da coisa pública, ou 
seja, os interesses privados sobrepondo o público, em detrimento da cidadania, na qual todos são cidadãos de plena igualdade.

Descortinamos em Sérgio Buarque de Holanda que o homem cordial é problemático para a modernização das instituições e para o estabelecimento de uma democracia moderna no país. Este autor toma os conceitos positivos e otimistas de Gilberto Freyre e os reinterpreta na perspectiva de constituição do homem brasileiro e suas instituições, ou seja, na compreensão de nossa identidade. Portanto, para Buarque de Holanda, o homem cordial, traço importante da identidade brasileira, tem dificuldade para distinguir o público do privado, portanto, é patrimonialista e naturaliza os desvios de recursos públicos e o tráfico de influência como normalidade da vida pública.

Florestan Fernandes expõe que uma nação não surge de uma hora para outra, mas se forma com o tempo. Por isso, a compreensão de uma nação acontece no desenvolver de sua história, ou seja, na longa duração. Para o autor, observa-se durante nossa história que a sociedade civil é eclipsada pelo estamento dominante, ou seja, pela monopolização do Estado pela burguesia, que se dotou de uma Constituição liberal sem construir um Estado liberal ou uma democracia liberal. Sendo, assim, uma característica identitária a coexistência do arcaico com o moderno, i.e., uma democracia restrita, pois é muito difícil realizar a ruptura com o passado, no qual as elites tradicionais se coligam com as modernas.

Florestan também evidencia de forma assertiva, e como característica identitária, que a igualdade não é para todos e que a revolução burguesa, que tem como pressuposto modernizar a sociedade, não se realizou no Brasil, ou se realizou apenas parcialmente, pois se apropria de elementos arcaicos, transportando o passado ao presente. Florestan aponta que a burguesia não universaliza a igualdade, todavia a estabelece entre os privilegiados, não sendo a ordem social moderna no Brasil democrática e aberta, senão para alguns, pois os direitos só existem dentro dos setores sociais dominantes; ou seja, a burguesia não realiza a revolução burguesa ao não romper com o passado e ao não universalizar a igualdade e a democracia.

Verificamos que em Victor Nunes Leal o fenômeno do coronelismo, resultado da rarefação do poder público, também se constitui em elemento central da constituição da identidade brasileira, pois essa relação de dependência, novamente, do arcaico com o moderno, está no âmago da subserviência e subcidadania. Nesse contexto, o voto possui pouco ou nenhum valor, pois as camadas inferiores sabiam que quem eles votavam não os representava. 
Gláucio Soares evidencia que o fenômeno da autoridade, sobretudo no interior e junto à camada da população com pouco ou nenhuma educação formal, mostra-se sagrada e fatalística, sem consciência de povo e cidadania. O autor atenta para a formação do caráter de submissão fatalística, a aceitação da pobreza como fato natural e o papel da Igreja na manutenção do status quo. Soares alerta também que o autoritarismo não é constituído apenas pelo período da ditadura civil-militar (1964-85), mas está presente em toda a história brasileira, o que igualmente deixa marca indelével na constituição de nossa identidade.

Simon Schwartmann, por sua vez, considera autoritária a relação do Estado para com a sociedade, na qual o Estado brasileiro domina a sociedade e esta, no seu todo, deve ser ordeira, pacífica e sem conflitos, não sendo bem-vindos os dissensos, conflitos e manifestações por parte desta. Para o autor, a sociedade, especialmente no seu segmento empresarial, aceita este domínio, pois depende e espera as benesses do Estado. $\mathrm{O}$ autoritarismo se traduz na cooptação ao Estado de certos segmentos importantes da sociedade civil, como o financeiro, o industrial ou o agronegócio. Assim, a esfera pública se deixa "colonizar" pelos interesses privados daqueles que controlam o Estado, continuando não haver separação entre o público e o privado e não se constituir, portanto, numa democracia e burocracia moderna.

Finalmente Jessé Souza aponta outra característica maior de nossa identidade: a "naturalização" das relações sociais de dominação no Brasil. Dessa forma, alerta o autor, que em vez de harmonia e pacificação social, há de se ver dominação de desigualdade. Contudo, tal dinâmica cria uma dominação simbólica extremamente eficiente, corroborando com a assertiva de Marx em sua obra A ideologia alemã: "o capitalismo desenvolve uma ideologia espontânea", na qual uma classe de pessoas tinha a função de legitimação: na Índia, os brâmanes, na China, os mandarins, no Ocidente, a Igreja Católica. Hoje, no Brasil, a educação, os meios de comunicação de massa e grande parte das diferentes denominações religiosas pentecostais fazem a legitimação do capitalismo gerador de excluídos. Assim, as diferenças sociais são legitimadas e o capitalismo é considerado justo, pois paga o que o operário merece e produz.

No contexto dessa legitimação, a obra de Jessé Souza, apoiada nos conceitos de Bourdieu, é meritória para desnaturalizar as relações sociais de dominação e exclusão que existem na aparente harmonia e pacificação social, encontradas nos conceitos de "democracia racial" e "homem cordial", formadores da identidade brasileira, em grande medida usados para seu proveito pelas elites dominantes que encontram nos meios de comunicação de massa sua voz. 
Como Marilena Chauí, uma filósofa que se pergunta pela identidade do Brasil e dos brasileiros, apontamos que as relações de dependência - caracterizadas por um senhor (patrão) que manda e um inferior que obedece, típico da cultura colonial que persiste hodiernamente estão impregnadas por todas as nossas relações sociais. Estas são, na verdade, relações sociais assimétricas que reforçam e naturalizam a desigualdade e a exclusão, sem o devido reconhecimento do subordinado, do outro, com sua subjetividade e alteridade. Essa questão, posta por diversos autores aqui trazidos, especialmente Gilberto Freyre, Sérgio Buarque de Holanda, Jessé Souza, entre outros, é constitutiva da identidade brasileira, que caracteriza-se por relações sociais permeadas pelas desigualdades, pelo desrespeito à pessoa do outro, especialmente quando esse outro é inferior hierarquicamente ou socialmente, mas que são, muitas vezes, travestidas pela cordialidade.

Através do nosso já longo processo histórico, a identidade brasileira foi sendo forjada no convívio, e mesmo naturalizando, acomodando-se, "dando-se um jeito" e convivendo com atributos do patrimonialismo, dos favorecimentos, da corrupção, da subserviência ou "submissão fatalística", da desigualdade excessiva e mesmo monstruosa, enfim, de não ser um povo político. Por sua vez, as elites dominantes, por meio de suas diversas formas de disseminar preventivamente suas ideologias, procuram consolidar a identidade do brasileiro como ser pacífico, cordial, amante da paz, entre outras qualificações, para evitar posicionamentos mais radicais com relação às desigualdades brutais ou mesmo certos tipos de manifestações. Todavia, o caráter pacífico é desafiado, e mesmo desmentido, pela dura realidade de violência física que convive-se país afora que iguala-se à violência das regiões do mundo que estão em guerra declarada, ou mesmo pela violência simbólica, na qual a classe que domina economicamente impõe sua cultura e ideologia aos dominados. Do mesmo modo, é escandaloso os diferentes pesos e medidas que a sociedade brasileira "aprendeu" a conviver e naturalizar. Destaca-se o valor da vida, da dignidade da pessoa e do roubo e corrupção que recebem diferentes pesos e punições de acordo com o estrato econômico-social, constituindo-se empecilhos para uma coesão social mais profunda, ou mesmo para construir um projeto de nação.

No decorrer deste trabalho, observamos que apesar da diversidade do fluxo de ideias e narrativas e do conjunto das questões abordadas, o caminho percorrido pela produção de conhecimento acerca do Brasil pauta-se pela indagação, que permeia todas as narrativas estudadas, sobre quem nós somos, como nos constituímos como povo, sociedade, Estado e nação. 
Ressalta-se nessas narrativas que a identidade brasileira é construída na relação de extrema desigualdade, de privilégios, de mando e dominação entre os supostamente iguais, chegando mesmo a comprometer a própria noção de cidadania e dignidade, bem como a legitimidade da lei.

Reconhecemos que este trabalho retrata a identidade brasileira com uma nota pessimista, visto a dificuldade persistente de construir uma verdadeira cidadania, com redução da desigualdade, e a complexidade de extirpar o predomínio da ordem privada sobre o político, o que torna característica central do Brasil como nação, certamente em construção.

Finalmente, pontuamos que o intento desta pesquisa foi o de mostrar a riqueza, a diversidade e a seriedade que a tarefa de desvendar o Brasil encarna em si e como se dão as relações entre atores e poder. O certo é que esta empreitada não se pode dar por encerrada, pois "o Brasil não é para amadores" e não há apenas um Brasil, mas vários brasis convivendo num mesmo território.

\section{REFERÊNCIAS}

ANDERSON, Benedict. Imagined communities: reflections on the origins and the spread of nationalism. Londres: Verso Editions \& New Left Books, 1983.

ANDRADE, lara. Algumas reflexões sobre o conceito de identidade nacional. In: ENCONTRO REGIONAL DA ANPUH RIO: MEMÓRIA E PATRIMÔNIO, 14, 2010, Rio de Janeiro. Anais... Rio de Janeiro: UNIRIO, 2010.

BENTHAM, Jeremy. Os pensadores. São Paulo: Abril Cultural, 1979.

BRAGA, Ruy. Decifrando o enigma brasileiro: novas pistas. RBCS, v.19, n.56, 2004.

CANDIDO, Antônio. O significado de 'Raízes do Brasil', Prefácio, ed. 1967. In: HOLANDA, S.B. Raízes do Brasil. 26ạ. ed. 19a. reimpressão. São Paulo: Companhia das Letras, 1995 [2004].

CARDOSO, Ruth. Prefácio. In: CASTELLS, Manuel. A era da informação: economia, sociedade e cultura Volume II: O poder da identidade. São Paulo: Paz e Terra, 2000.

CARVALHO, José Murilo de. História intelectual no Brasil: a retórica como chave de leitura. Topoi Revista de História, Rio de Janeiro, v.01, n.01, p. 123-152, jan-dez.2000.

CHAUÍ, Marilena. Brasil: o mito fundador e sociedade autoritária. São Paulo: Fund. Perseu Abramo, 2000.

DOMBROWSKI, Osmir. Reforma agrária no Brasil: primeiros projetos (1945-1955). Dissertação de mestrado. São Paulo: USP, 1998.

DUARTE, Nestor. Reforma agrária. Rio de Janeiro: Imprensa Nacional, 1953.

FAORO, Raymundo. Os donos do poder: formação do patronato político brasileiro. 10a. ed. São Paulo : Globo: Publifolha, 2000.

FOUCAULT, Michel. A ordem do discurso. 17ạ ed. São Paulo: Edições Loyola, 1996. 
FREYRE, Gilberto. Casa grande \& senzala: formação da família brasileira sob o regime da economia patriarcal. 12 . ed. Brasilia : Ed. Universidade de Brasília, 1963.

GELLNER, Ernest. Nation and Nationalism. Oxford: Basil Blackwell, 1983.

HALL, Stuart. A Identidade cultural na pós-modernidade. 11a. ed. Rio de Janeiro: DP\&A, 2006.

HOLANDA, Sérgio Buarque de. Raízes do Brasil. 26ạ. ed. 19ạ. reimpressão. São Paulo: Companhia das Letras, 1995 [2004].

LEAL, Victor Nunes. Coronelismo, enxada e voto: o município e o regime representativo no Brasil. 4a. ed. São Paulo: Companhia das Letras, 2012.

MOTA, Carlos Guilherme. Ideologia da Cultura Brasileira: 1933-1974. São Paulo: Ática, 1990.

ORTIZ, Renato. Cultura Brasileira e Identidade Nacional. São Paulo: Brasiliense, 1994.

PRADO JUNIOR, Caio. Formação do Brasil contemporâneo: colônia. São Paulo: Brasiliense : Publifolha, 2000.

RENAN, Ernst. What is a nation?. In Bhabha, H. (org.). Narrating the Nation. Londres: Routledge, 1990.

RICUPERO, Bernardo. Sete lições sobre as interpretações do Brasil. São Paulo: Alameda Casa Editorial, 2008.

SCHWARTZMAN, Simon. Bases do Autoritarismo Brasileiro. 4a. ed. Rio de Janeiro: Publit Soluções Ed., 2007.

SCRUTON, Roger. Authority and allegiance. In: DONALD, J.; HALL, S. (orgs.) Politics and Ideology. Milton Keynes: Open University Press, 1986.

SOARES, Gláucio A. D. A democracia interrompida. Rio de Janeiro: Ed. FGV, 2001.

SOUZA, Jessé. Construção Social da Subcidadania. Belo Horizonte: Ed. UFMG, 2006.

UFPR, 1010.

O mito brasileiro. Palestra proferida em 30/11/10 na Universidade Federal do Paraná. Curitiba:

TORRES, Alberto. A organização nacional: introdução a um programa de organização nacional. 4ạ. ed. São Paulo; Brasília (DF): Ed. Nacional: Ed. Universidade de Brasília, 1982.

VIANNA, Oliveira. Populações meridionais do Brasil. Rio de Janeiro: Paz e Terra, 1973-1974.

WEBER, Max. Ensaios de Sociologia. 5. ed. Rio de Janeiro, 2002. 